\title{
Oil Extraction from Two Species of Sesame (Sesamum Indicum) and the Chemical Composition of the Meal
}

ISSN: 2637-7659

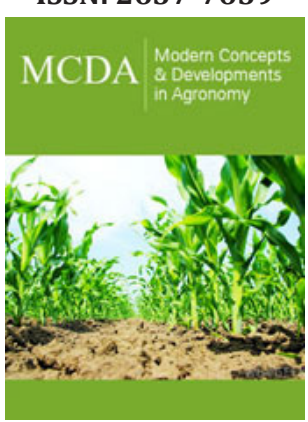

*Corresponding author: ALANE Farida, Institut National de la Recherche Agronomique d'Algérie (INRAA) Baraki, Algeria

Submission: 監 May 26, 2021

Published: 眥June 15, 2021

Volume 8 - Issue 5

How to cite this article: ALANE Farida, GUINDO Koudédia Drome, AMALO Djamel. Oil Extraction from Two Species of Sesame (Sesamum Indicum) and the Chemical Composition of the Meal. Mod Concep Dev Agrono. 8(5). MCDA. 000698. 2021. DOI: 10.31031/MCDA.2021.08.000698

Copyright@ ALANE Farida. This article is distributed under the terms of the Creative Commons Attribution 4.0 International License, which permits unrestricted use and redistribution provided that the original author and source are credited.

\author{
ALANE Farida ${ }^{1 *}$, GUINDO Koudédia Drome ${ }^{2}$ and AMALO Djamel ${ }^{2}$ \\ ${ }^{1}$ Institut National de la Recherche Agronomique d'Algérie (INRAA) Baraki, Algeria \\ ${ }^{2}$ Université Saad Dahleb Blida, Algeria
}

\begin{abstract}
Subject description: the objective of this work and to exploit the product and the by-Product of sesame grown in Mali.

Method: Two methods are used, one mechanical and the other chemical, to evaluate the yield and the quality of the product.

Result: After extracting the oil (fat: MG) with a compress, the oil cake still contains $31.95 \%$ of it, which must be exploited either by improving the extraction method, or by using it in animal feed. Besides whatever the chemical used for the extraction, the result is almost the same $51.59 \%$ and $50.62 \%$ respectively with benzene and petroleum ether. On the other hand, the average fat content (MG) differs from the Malian species (ESE1) to that marketed (ESP) in Algeria, as well as the mineral content. However, the protein content is the same $18.5 \%$ DM. The two elements, proteins and minerals increase after extraction of MG. Meal is a free source of fat for animals. The fiber content before extraction was $19.75 \%$ then increased in the cake to $35.78 \%$. This rate can be improved for good digestibility.
\end{abstract}

Conclusion: The oil yield by the mechanical method can be improved by increasing the extraction pressure.

Keywords: Sesame; Fat; Oil cake; Chemical composition

\section{Introduction}

Requires money to acquire the necessary equipment to improve the yields of agricultural, pastoral and fish farming activities, the main sources of income in rural areas [1]

Globally, Malian agriculture occupies 2/3 (66.66\%) of production and provides most of the food for humans and animals; it supplies raw materials to industry [2].

The colonial administration in Mali introduced a dichotomy between agricultural products by placing them in two categories: food crops, self-consumption, and subsistence on the one hand; industrial, cash or cash crops on the other side. The latter were encouraged by force first, then by pressure of all kinds on the country. This is the case for coffee, cocoa, cotton, sugar cane and sesame among others [3]. Mali is the world's largest producer of organic sesame, its purchase at a remunerative price is guaranteed by the company which supervises the producers OHVN (the Office de la haute Vallée du Niger) [3].

The genetic diversity of the genus Sesamum is broad examples six wild species of the genus namely, Sesamum mulayanum, Sesamum capense, Sesamum laciniatum, Sesamum latifolium, Sesamum occidental and Sesamum schinzianum [4].

Cultivated sesame (Sesamum indicum) is a plant of the Pedaliaceae family, an agricultural product widely cultivated for its seeds, 0.5 to $2 \mathrm{~m}$ high depending on climatic conditions. 
It is cultivated in Asia, America, Europe and Africa. Not very demanding in terms of water and manure and it adapts to various types of climates. Its production has various uses. The production area in Africa is expanding under the pressure of "demand on the international market, greater than supply" [5].

Asia provides $70 \%$ of world production; America and Europe respectively at 4.98 and $0.038 \%$. Africa contributes $15 \%$ [2].

[6] revealed the presence of genetic variability in sesame for seed yield significantly and stated that crosses of parental genotypes have the potential to increase total seed yield of sesame.

Nutritional quality and oxidative stability are two main factors in the evaluation of edible oils. The quality characteristics and composition of sesame oils prepared using a household electric oven suggests that a high-quality product would be obtained by roasting for $25 \mathrm{~min}$ at 160 or $180^{\circ} \mathrm{C}, 15 \mathrm{~min}$ at $200{ }^{\circ} \mathrm{C}$. and $5 \mathrm{~min}$ at $220^{\circ} \mathrm{C}$ compared to other samples [7].
To learn more about the yield and quality of the oil produced by mechanical and chemical methods as well as the exploitation of the residue in ruminant feed; we have undertaken to conduct the research of nutritional value through the physical and chemical composition of the oil and its cake of two cultivars of Sesamum indicum one of Malian origin and the other of Sudanese origin.

\section{Material and Methods}

\section{Origin of plant material}

The first species, Sesamum samples studied, comes from Mali from the Koulikoro region located east of Bamako. The second species comes from the Algerian market (Sudan).

\section{Extraction and dosing}

The plant material (sesame seeds) was subjected to oil extraction and chemical analysis before and after extraction. The oil was subsequently analyzed. Figure 1 brings together all the stages of the experimental approach followed.

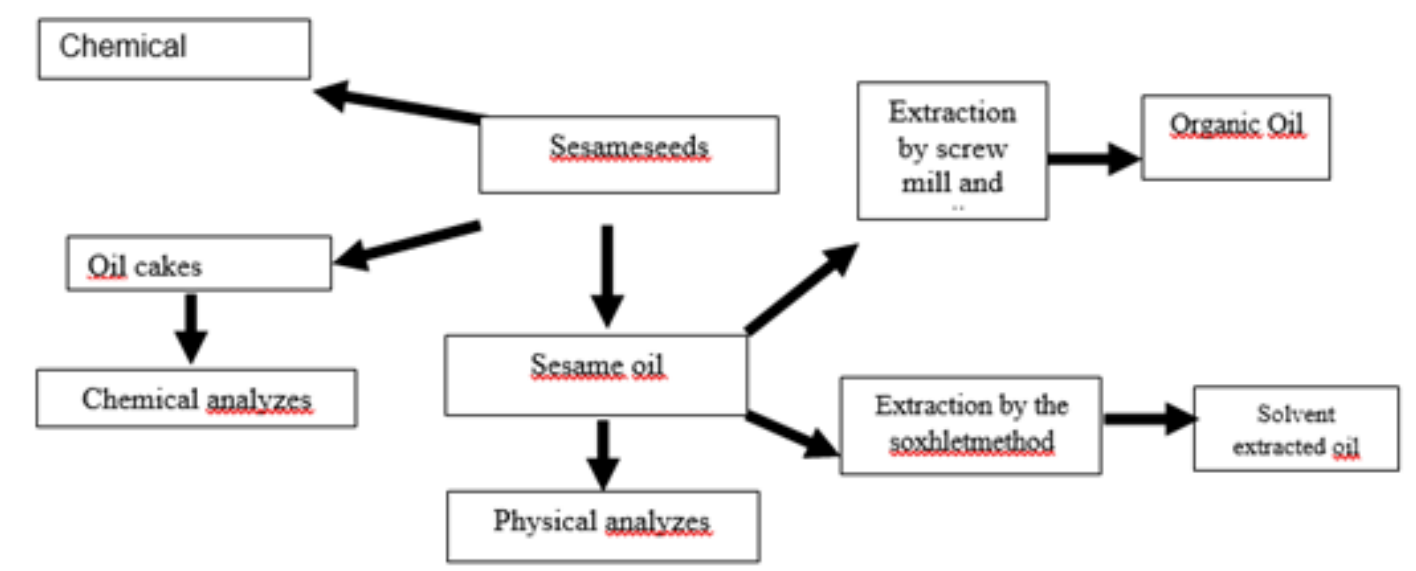

Figure 1: Summarizes the experimental approach followed.

\section{Oil extraction from sesame seeds}

By the solvent: From the flour resulting from the grinding of sesame seeds, we proceeded to extract the oil using the soxhlet extractor. The solvents used are n-hexane, petroleum ether and benzene. For each sample of about $10 \mathrm{~g}$ we have used a sufficient amount, the cup is not large so that once it is empty, we fill it. The extractions were carried out for $4 \mathrm{~h}$ with $\mathrm{n}$-hexane and petroleum ether and $3 \mathrm{~h} 30$ benzene at a temperature of $90^{\circ} \mathrm{C}$ and $100{ }^{\circ} \mathrm{C}$. The soxhlet extraction used is composed of 3 essential parts:

i. The ball or a glass.

ii. The cartridge column and the refrigerant.

iii. A water cooler.

By compress: After mechanical grinding (Figure 1) of sesame seeds (200g) using a screw mill (Figure 2), the paste obtained is manually pressed with a compress (tulle) in a glass (Figure $3 \& 4$ ). The oil obtained is measured by test tube to assess the yield of the seeds weighed beforehand.

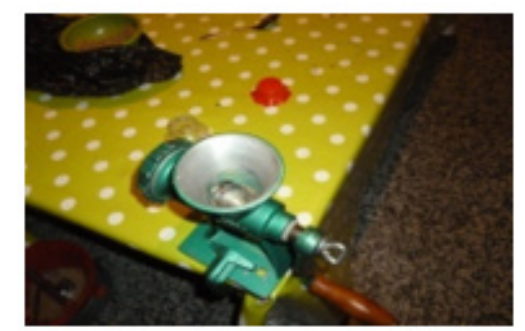

Figure 2: Extraction by screw mill.

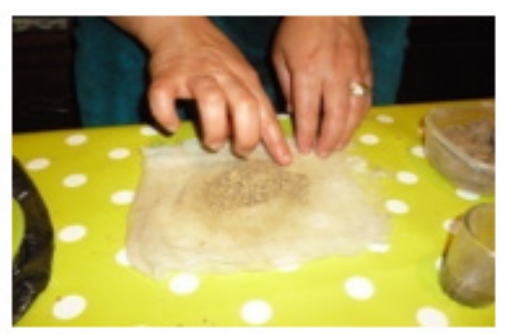

Figure 3: Physical analyzes. 


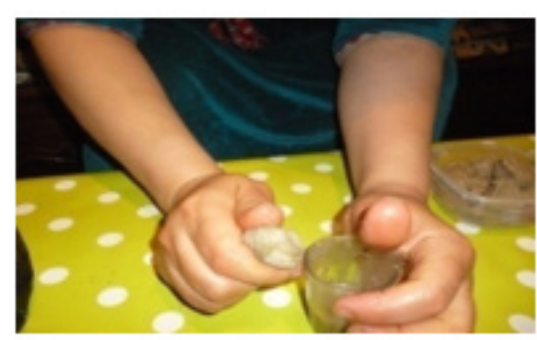

Figure 4: The paste obtained is manually pressed with a compress (tulle) in a glass.

\section{Seed and meal analysis process}

Crushing of samples before analysis. Depending on the fineness of the ground material obtained (fibers $>1 \mathrm{~mm}$ or fine dust).

Chemical analyzes of sésame flour and meal: In order to know the nutritional value of the flour and meal of the two species studied, we carried out the chemical analyzes according to the intentional ISO standards reported in the following book of fodder analyzes [8]

Détermination of Dry Matter (DM) / water content: Put empty weighing vessels, previously dried in the oven, for at least 1 hour in a desiccator. After cooling, tare to the nearest $0.1 \mathrm{mg}$ for each weighing vessel. Let $\mathrm{M}_{0}$ be their mass. Weigh into the vessels, to the nearest $0.1 \mathrm{mg}$, about $3 \mathrm{~g}$ of ground sample. Let PE be the test socket. Spread the test sample evenly with a slight rotary motion. Place the full weighing vessels in an oven at $103{ }^{\circ} \mathrm{C}$ for $24 \mathrm{~h}$. The timer will be started as soon as the oven has reached the desired temperature again. After 24 hours, take out the weighing vessels and allow them to cool in a desiccator. Weigh them to the nearest $0.1 \mathrm{mg}$. Let $\mathrm{M}_{1}$ be their mass.

Calculation of dry matter (DM):

$$
\begin{gathered}
\% D M=\frac{M 1-M 0}{P E} \times 100 \\
\% \text { Humidity }=100-\% D M
\end{gathered}
$$

$\mathrm{M}_{0}$ : The mass of the empty crucible.

$\mathrm{M}_{1}$ : The mass of the crucible containing the dry residue, in grams.

Determination of ash/mineral content (MM): The mineral matter is obtained after destruction of the organic matter by incineration. Put the nickel crucibles which were used to determine the dry matter for at least 1 hour at $200{ }^{\circ} \mathrm{C}$ in the muffle oven and then calcine for 2 hours at $550{ }^{\circ} \mathrm{C}$. The stopwatch will be started as soon as the oven has reached the desired temperature.

\section{The calculation}

$$
\% M M=\frac{M 1-M 0}{P E} \times 100
$$

With: MM: the mineral content expressed as a percentage of the raw product.

$\mathrm{M}_{0}$ : the mass in grams of the empty crucible.
$\mathrm{M}_{1}$ : the mass in grams of the crucible containing the ashes. Then expressed in \% DM.

Crude Fiber (CF) WENDE method: The sample is treated with a $1.25 \%$ solution of sulfuric acid and then with a $1.25 \%$ solution of sodium hydroxide. Each treatment lasts $30 \pm 1 \mathrm{~min}$. The residue is each washed with hot water and dried. Finally, the residue is calcined for 1 hour at $530^{\circ} \mathrm{C}$.

The calculation of crude cellulose (CF):

$$
C F \% D M=\frac{(P 1-P 2)}{E} \times 100 / D M \times 100
$$

P1: Obtaining the residue (P1) after 24 hours in the oven.

P2: Incineration of the residue at $550^{\circ} \mathrm{C}$ for 4 hours (P2).

Determination of total nitrogen: kjeldahl method: In a plant or even in a soil, nitrogen can be found in mineral and organic form (proteins, phospho-amino-lipids); to dose it in its entirety, it is necessary to destroy the organic compounds so as to obtain all the nitrogen in the same mineral form. Mineralization is carried out for this. The nitrogen is then dosed by acid-base assay.

Calculation of the amount of nitrogen $(\mathrm{N})$ :

$$
N(g)=\frac{(A-B) \times N \times 280 \times 10^{-6} \times 12.5 \times 100}{P}
$$

A: Quantity of sulfuric acid required for the titration of the sample (ml).

B: Quantity of sulfuric acid required for the titration of the control (ml).

$\mathrm{N}$ : Normality of sulfuric acid.

P: Test portion (g).

$$
C P \% D M=N(g) \times 6.25
$$

Determination of fat: The soxhlet method is already described above. Calculation of fat (MG).

$$
M G \% D M=\frac{A-B}{C} \times 100 / D M \times 100
$$

A: Weight of balloon or glass in g with fat.

$\mathrm{B}$ : Weight of the balloon or glass in $\mathrm{g}$.

C: Weight of the initial sample in $g$.

Physical analysis: The oils (obtained by the soxhlet method or by pressing with a compress) have undergone three tests:

i. Taste: a few drops of oils from each extraction are deposited in the tongue and turned in the mouth.

ii. Color: visually, the color of each variety is determined.

iii. Touch: with two fingers, index and push the oil is rubbed to assess the degree of roughness.

\section{Result and Discussion}

The two cultivars studied (Table 1) have seed colors and the weight of a thousand different seeds. The physicochemical 
properties of sesame seeds vary according to several parameters including the aspect: genetics, maturity of the seed, harvesting and storage conditions. [7], showed in their study of the genetic diversity of Sesamum indicum, the varieties offer more oils than populations.

The Malian species is heavier so the seedling dose will be lower than the species marketed in Algeria. It is an important cash crop for small farmers and farmers $[9,10]$.

For both species the biological extraction method gives a cloudy appearance to the oil which requires its purification by centrifugation or decantation. On the other hand. Solvent extraction, the oil of the species is creamy yellowish. According to [11], the design of an extraction system meeting predefined objectives requires the choice of solvents essentially according to their polarity, the aim of which is to optimize the extraction

Manual extraction (with the screw and tulle mill) of $200 \mathrm{~g}$ of Malian sesame seeds offers a volume of $75 \mathrm{ml}$, is a yield of $37.5 \%$. On the other hand, the extraction with the petroleum ether solvent of $10.18 \mathrm{~g}$ of Malian sesame acquires $5.25 \mathrm{~g}$ of oil, is a yield of $51.55 \%$.
Although the extraction of sesame oil with the screw and tulle mill gives a lower fat value than that obtained by the soxhlet method, the quality of the latter is better and will bring in more money. It is more in demand for human consumption. The cakes obtained after extraction can be used to feed livestock. Thus, the product and byproduct of organic sesame do not carry a risk of toxicity.

According to the species after extraction with a compress, the oil cakes still contain on average $29.28 \%$ fat and $46.26 \%$ fat respectively Malian species and species from the Algerian market (Table 2). This must be exploited either by improving the extraction method (example using a press), or by using oil cakes in animal feed. In the literature, the oil cake of sesame oil extraction by pressure still contains $8-10 \%$ of residual oil [12].

In addition, whatever the solvent used for the extraction, the result is almost the same $51.59 \%$ and $50.62 \%$ respectively with benzene and petroleum ether (Table 2). According to some authors, Wang et al. [13] the extraction yields of sesame oils were largely dependent on the extraction solvent, there is a solute-solvent interaction.

Table 2: Chemical characteristics of the oils and cakes of the two sesame species studied.

\begin{tabular}{|c|c|c|c|c|c|c|c|}
\hline \multirow{2}{*}{$\begin{array}{l}\text { Settings } \\
\text { Samples }\end{array}$} & \multirow[t]{2}{*}{$\%$ of Humidity } & \multirow[t]{2}{*}{ DM\% } & \multicolumn{5}{|c|}{ Expressed as\% of DM } \\
\hline & & & ММ\% & $\mathrm{CP} \%$ & CF \% & MG\% Benzene & MG\% Petroleum Ether \\
\hline Seed sample 1 of Malian species & 4.03 & 95.96 & 5.59 & 17.74 & 13.41 & 49.95 & 48.61 \\
\hline Seed sample 2 of Malian species & 3.96 & 96.03 & 5.92 & 19.15 & 26.09 & 53.23 & 52.62 \\
\hline Average & 3.99 & 96 & 5.75 & 18.44 & 19.75 & 51.59 & 50.62 \\
\hline Sample 1 meal Malian species & 4.31 & 95.68 & 6.3 & 24.26 & 17.83 & 26.61 & \\
\hline Sample 2 meal Malian species & 4.26 & 95.73 & 6.21 & 22.2 & 35.78 & 31.95 & \\
\hline Average & 4.28 & 95.71 & 6.25 & 23.23 & 26.8 & 29.28 & \\
\hline $\begin{array}{l}\text { Sample } 1 \text { of seeds species of the } \\
\text { Algerian market }\end{array}$ & 3.15 & 96.85 & 10.35 & 17.61 & 14.05 & 41.77 & 49.91 \\
\hline $\begin{array}{c}\text { Sample } 2 \text { of seeds species from the } \\
\text { Algerian market }\end{array}$ & 3.17 & 96.83 & 10.67 & 17.79 & 14.38 & & 49.91 \\
\hline Average & 3.16 & 96.84 & 10.51 & 17.7 & 14.22 & & 49.91 \\
\hline $\begin{array}{l}\text { Sample } 1 \text { tourteau species from the } \\
\text { Algerian market }\end{array}$ & 3.56 & 96.44 & 3.61 & 18.36 & 18.14 & & 46.98 \\
\hline $\begin{array}{c}\text { Sample } 2 \text { brown crab species from } \\
\text { the Algerian market }\end{array}$ & 4.3 & 95.7 & 3.34 & 17.88 & 16.79 & & 45.54 \\
\hline Average & 3.93 & 96.07 & 3.47 & 18.121 & 17.46 & & 46.26 \\
\hline
\end{tabular}

Polar solvents are considered to be bio-renewable promoters for the extraction of oils. Their action manifests itself through the rupture of cell walls allowing a more in-depth extraction of cellular content $[13,14]$.

However, the average fat content in the seeds differs from one species to another. The Malian species (ESE1) records 51.59\% and that marketed in Algeria (ESP2) allocates 49.91\% (Table 2). These results are in agreement with the observations reported in the literature ranging between 43 and 58\% [15,11].

The literature shows that there is not much variability in the ash content of sesame seeds, between 3.7\% and 6.5\% [15]. Several other authors claim that the content depends essentially on the growing medium of the plant. Our results vary between 5.57\% DM and $10.51 \%$ DM respectively for the Malian species and the species of the Algerian market. These proportions increase in the meal of the first species and decrease in the second species (Table 2).

The protein content in sesame seed is almost the same 17.7 and $18.4 \%$ so it is a species-specific value. However, various authors have shown that the average protein content of sesame seeds is between $16.3 \%$ and $25 \%$ [15]. Thus, the improvement of the content in this parameter is possible by selection.

After extraction of the oil, that is to say in the oil cakes, the protein levels change in the Malian species (from $18.44 \%$ to $23.33 \%$ expressed in \% DM), in the species imported in Algeria increased 
by $(17.7 \%$ to $18.12 \%$ expressed in $\% \mathrm{DM})$, which is a free source for animal feed. Non-enzymatic browning can lead to a decrease in nutritional properties with a decrease in the digestibility of proteins and in the solubility of the product leading to the loss of amino acids, vitamins and development of the undesirable flavor with change in texture and increase in acidity [16].

The average moisture content of the seed meal of the two species is the same due to the presence of the seed coat in the seed. The disappearance of the latter during grinding increases the humidity of the oil cakes from 3.99 and 3.16 to $4.26 \%$ (Table 2). Despite the similarity of the color of sesame seeds, their moisture content is different [11]. [17] Found in seed varieties originating in Nigeria a humidity of $4.73 \pm 0.02 \%$ of black color, $4.12 \pm 0.01 \%$ for seeds of brown color and $4.14 \pm 0.05 \%$ for white seeds. [18] reported that the moisture content of different cultivars from different countries was between 3.65 and 5.60 .

Water contents between $5.3 \%$ and $8 \%$ have been reported by [19]. Nigerian sesame with an average water content of $3 \%$ is considered a dry product. This could be due to the warm climate and the mode of drying and storage [19].

The fiber content before and after fat extraction is different. Thus, in both species, oil cakes have a higher proportion of fibers (CF) than sesame flour before extraction; in the Malian species increased from $19.75 \%$ to $35.78 \%$ while the species imported into Algeria increased from $14.22 \%$ to $17.5 \%$ (Table 2).

Everything depends on the ration of the animal this rate can be improved for good digestibility when already a rate of $30 \%$ is considered good for rumination according to [20,21].

\section{Conclusion}

The physico-chemical analysis of the sesame seeds and the physical sesame oil of the two cultivars studied reveals a very interesting fat content of $49.91 \%$ and $51.59 \%$ with the soxhlet method. With mechanical extraction, the quantity is much less than $32 \%$ but can increase after improvement of the extraction method. However, this even small amount will cost more than that which will carry traces of solvent is a source of currency. In any case, sesame oil is an economic source not to be overlooked by the Malian farmer. It is within reach of the farmer or a group of farmers. The organic extraction method is easy to carry out by the Malian woman, whose oil can be used in cooking. The meal obtained from the extraction can be used in animal feed, and in the preparation of mixtures of concentrate in industries which import soybean meal.

\section{References}

1. Koressi Y (2010) Inventaire des techniques de conservation du sésame. Rapport de développement économique rural de la région de Kolikaoro, laboratoire de technologie alimentaire. Mali, West Africa, p. 17.

2. FAO (2012) Statistiques sur la production de sésame entre 2005 et 2009. Rome: FAOSTAT, Italy.
3. Ouattara B (1985) Etude de la variabilité dans une collection de sésame (Sesamum indicum L.). Mémoire de fin d'études. Institut Supérieur Polytechnique (I.S.P.), Université d'Ouagadougou, Burkina Faso (BF), p. 77.

4. Hiremath SC, Patil CG, Patil KB, Nagasampige MH (2007) Genetic diversity of seed lipid content and fatty acid composition in some species of Sesamum L. (Pedaliaceae). African Journal of Biotechnology 6(5): 13-19.

5. Habibou I (2006) Etude de la filière Sésame dans la zone d'Intervention du Projet de Promotion des Initiatives Locales pour le Développement d'Aguié (PPILDA). cas de la zone de Gawaro Sud Tchadoua (Aguié). Mémoire présenté en vue de l'obtention du diplôme de maîtrise en géographie Université Abdou Moumouni de Niamey Niger, p. 71.

6. Navaneetha J, Murugan, E, Parameswari C (2019) Components in sesame (Sesamum indicum L.). Elect J Plant Breed 10: 1262-1268.

7. Wan JP, Phillip JW (1997) Technology and solvents for extracting oil seeds and non-petroleum oils. AOCS Press, Champaign, Illinois, USA.

8. AFNOR (Association Française de Normalisation) (1985) Aliments de l'animales méthodes d'analyses françaises et communautaires. $\left(2^{\text {nd }}\right.$ edn), p. 399.

9. Uzun BS, Ülger, Ilhan C (2002) Comparison of determinate and indeterminate types of sesame for oil content and fatty acid composition. Turk J Agric Forestry 26(5): 269-274.

10. Arslan C, Uzun B, Ülger S, Ilhan C (2007) Determination of oil content and fatty acid composition of sesame mutants suited for intensive management conditions. Journal of the American Oil Chemists' Society 84(10): 917-920.

11. Tir R (2013) Extraction et caractérisation de l'huile de graines de sésame de diverses origines, étude de l'influence du solvant de la méthode d'extraction et de la torréfaction sur la composition chimique de l'huile. Thèse de doctorat en chimie, Uni de USTB. p. 161.

12. Frank DG (2011) Vegetable oils in food technology. Composition, Properties and Uses, Edition Blackwell Publishing, Hoboken, New Jersey, USA, p. 305.

13. Wang S, Basten C, Zeng Z (2007) Effects of seed roasting temperature and time on the quality characteristics of sesame (Sesamum indicum) oil.

14. Windows QTL Cartographer 2.5. Department of Statistics, North Carolina State University, Raleigh, North Carolina, USA.

15. Saxena DK, Sharma SK, Sambi SS (2011) Kinetics and thermodynamics of cotton seed oil extraction. Grasas Aceites 62(2): 198-205.

16. Weiss EA (1983) Oil seed crops. Logman, New York, USA, p. 305.

17. Villota R, JG Hawkes (1992) Reaction kinetics in food systems. In: Handbouk of food Engineering, Heldman DR, Lund DB (Eds.), Marcel Dekker, New York, USA, pp: 39-144.

18. Dashak A, Fali CN (1993) Chemical composition of four varieties of Nigerian benniseed (Sesamum indicum). Food Chem 47(3): 253-255.

19. Bahkali AH, Hussain MA, Basahy AY (1998) Protein and oil composition of sesame seeds (Sesamum indicum L) drown in the Gizan area of Saudi Arabia. International Journal of Food Sciences and Nutrition 49(6): 409414.

20. Gopalan C, Balasubramanian SC (1982) Nutritive value of Indian food. National institute of nutrition of India Council of Medical Research, Hyderabed, India.

21. Jarrige R, Ruckebusch Y, Demarquilly C, Farce MH, Journet M (1995) Nutrition des ruminants domestiques. Ingestion et digestion. INRA, Paris, France, p. 921.

For possible submissions Click below: 